
LIBRARY

MEYM. ONTARIO MUSEUM 


Life Sciences Contribution 73

Royal Ontario Museum

\section{A New Bat of the Genus Vampyressa} from Guyana, South America

R. L. Peterson ROYAL ONTARIO MUSEUM LIBRARIES

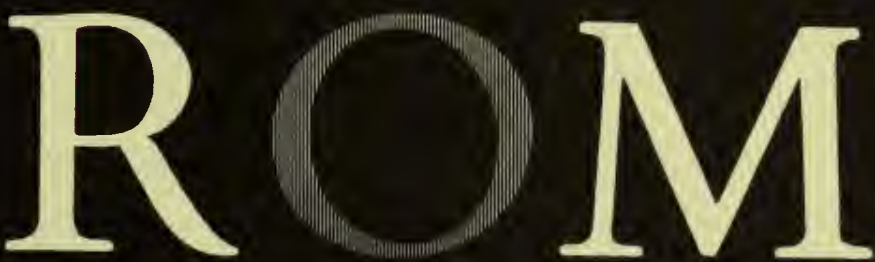


Digitized by the Internet Archive in 2011 with funding from University of Toronto 
Contribution No. 73

LIFE SCIENCES

ROYAL ONTARIO MUSEUM

L. Peterson A New Bat of the Genus Vampyressa from Guyana, South America with a Brief Systematic Review of the Genus

Publication date: 20 September, 1968

Suggested citation: Life Sci. Contr., R. Ont. Mus.

PRICE：\$1.00 
ROYAL ONTARIO MUSEUM

\section{PUBLICATIONS IN LIFE SCIENCES}

The Royal Ontario Museum publishes three series in the Life Sciences:

LIFE SCIENCES CONTRIBUTIONS, a numbered series of original scientific publications, including monographic works.

LIFE SCIENCES OCCASIONAL PAPERS, a numbered series of original scientific publications, primarily short and usually of taxonomic significance.

LIFE SCIENCES MISCELLANEOUS PUBLICATIONS, an unnumbered series of publications of varied subject matter and format.

All manuscripts considered for publication are subject to the scrutiny and editorial policies of the Life Sciences Editorial Board, and to review by persons outside the Museum staff who are authorities in the particular field involved.

LIFE SCIENCES EDITORIAL BOARD, 1968

Chairman: P. C. SWANN

Director, Royal Onturio Museum

Editors: w. B. SCOTT

Curator, Department of Ichthyology and Herpetology

G. B. WIGGINS

Curator, Department of Entomology and Invertebrate Zoology

RANDOLPH L. PETERSON is Curator, Department of Mammalogy, Royal Ontario Museum, and Associate Professor, Department of Zoology, University of Toronto.

(C) The Trustees of the Royal Ontario Museum, 1968

PRINTED AT THE UNIVERSITY OF TORONTO PRESS 


\title{
A New Bat of the Genus Vampyressa from Guyana, South America, with a Brief Systematic Review of the Genus
}

\begin{abstract}
A new species of bat of the genus Vampyressa, subfamily Stenoderminae, family Phyllostomidae, is described from Guyana, thus extending the known range of the genus to northeastern South America. The status of the species previously included in the genus Vampyressa and Vampyriscus is reviewed. The latter is regarded as a subgenus of the former and a new subgenus is described to contain Vampyressa nymphae and the newly described species.
\end{abstract}

Among a rather extensive collection of mammal specimens collected for the Royal Ontario Museum in southern Guyana and adjacent regions by Mr. Stanley E. Brock is a single specimen of Vampyressa from south central Guyana, some 800 miles from the previously known range of this genus. Comparisons with the known species of Vampyressa and related genera indicate that this specimen represents a new species. I take pleasure in naming it after Mr. Brock in recognition of his outstanding efforts and assistance in building up the most extensive collection of Guyana mammal specimens now in existence.

\section{Vampyressa brocki sp. n.}

TYPE. R.O.M. No. 38515, adult female (lactating condition), preserved in alcohol with skull extracted; collected in March 1966 on the upper headwaters of the Kuitaro River approximately 40 miles east of Dadanawa at Ow. wi-dy-wau (Oshi Wau head near Marurawaunowa), $2^{\circ} 50^{\prime}$ N., $58^{\circ} 55^{\prime}$ W., Rupununi District, Guyana, by Stanley Brock (Field No. 8039).

RANGE. Known only from the type locality.

DIAGNOSIS. A small species similar in size to $V$. pusilla thyone but more closely allied with $V$. nymphaea in most cranial and external characteristics, including a dark stripe extending from the base of the nose-leaf on either side of the eye to the base of the ear, with a strongly contrasting broad white stripe above and a less distinct. white stripe below; greyish brown above with a faint indistinct dorsal whitish stripe. Upper inner incisors relatively long, closely appressed distally and without strong bilobation; anterior nasal aperature with a broad horizontal base above the incisors; anterior upper premolars relatively small and in contact with canines and separated from posterior premolars by a space; crowns of posterior upper premolar approaching a quadrate shape in occlusal outline with the 


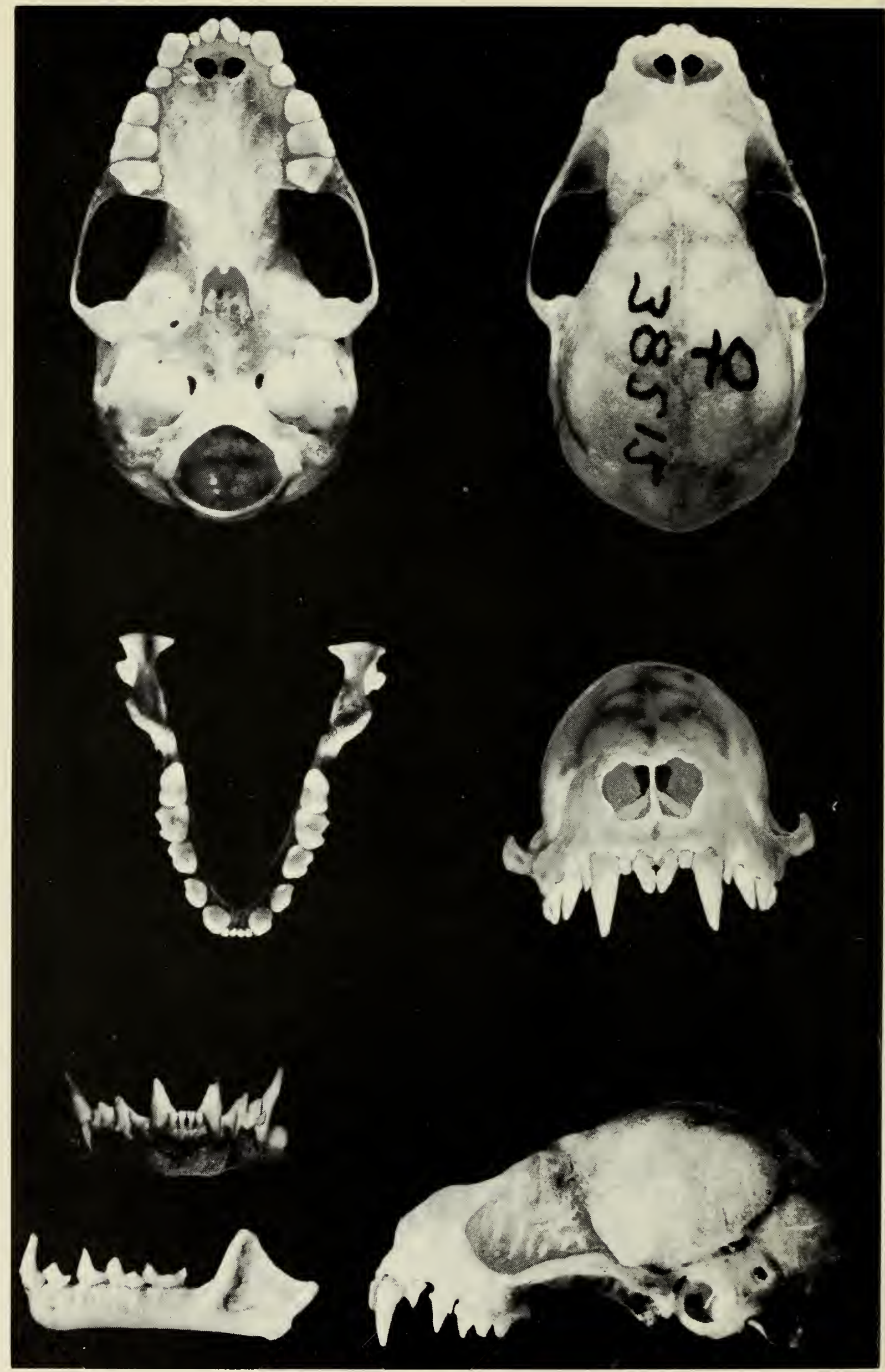

Fig. 1-Skull of the holotype of Vampyressa brocki, sp. n. 
posterior margin broad and parallel with $\mathbf{M}^{1} ; \mathbf{M}^{2}$ with rounded inner posterior portion (heel) with a notch formed posteriorly with outer cusps; posterior palate margin with a median projection; lower incisors with inner pair slightly narrower than outer; anterior lower premolar relatively low with blade-like lateral profile; posterior lower premolar with well developed shelf-like posterior heel; $\mathbf{M}_{2}$ noiiceably longer than wide with relatively low anterior and posterior cusps (see Figs. 1 and 2).

MEASUREMENTS OF THE TYPE. (All measurements in millimetres.) Forearm, 32.4; head and body length, 47; hind foot, 7; ear from notch, 14; height of tragus, 6 ; tibia, 11.7; calcar, 4.2; third digit-metacarpal, 33.1; first phalanx, 11.3; second phalanx, 16.2; fourth digit-metacarpal, 32.5; first phalanx, 9.6; second phalanx, 10.1; fifth digit-metacarpal, 32.6; first phalanx, 8.0; second phalanx, 8.5. Skull: greatest length, 17.8; condyloincisive length, 15.5; palatal length (incl. incisors), 8.3; zygomatic width, 10.4; mastoid width, 8.9; width across postorbital process, 4.7 ; least interorbital breadth, 4.5; least postorbital breadth, 4.65; $\mathrm{M}^{1}-\mathrm{M}^{1}, 7.4 ; \mathrm{C}-\mathrm{M}^{2}$, 5.9; C-C, 4.2; length of mandibles (condylo-incisive), 10.5; height of ramus, $3.6 ; \mathrm{c}-\mathrm{m}_{2}, 6.1$.

DESCRIPTION. General body coloration similar to $V$. nymphaea but pelage on dorsum strongly tricoloured with dark base and pale central band and dark terminal tips (Fig. 2C). Ears quite similar to $V$. bidens, being rather pale, edged with white or yellow, with a conspicuous lobe on the anterior upper base (above the tragus), a slight emargination on the outer rim of the pinna, an indistinct lateral lobe and a distinct basal truncated lobe. The tragus is pointed and thickened at the tip with a finely serrated outer margin above a more deeply scalloped basal region. It is joined to the head by a swollen lobe, that appears to be glandular in nature, with dark pores and associated long hairs. This lobe is essentially the same in $V$. bidens where there appears to be a sexual variation in its development, it being larger and with more glandular pores in the male (see Fig. 3 ). The base of the nose-leaf and lateral edges of the lancet are light coloured with a contrasting darker mid-rib which projects as a sharp spike. The terminal margins of the lancet tend to wrap around the mid-rib and come together on its posterior margin near the apex. In general, the nose-leaf is quite similar to $V$. bidens but shorter (see Fig. 2A and B). The interfemoral membrane is rather broad and not deeply incised. In the preserved type, the depth of the membrane at the midline appears to be about equal to the length of the tibia, and the body pelage extends slightly on to its dorsal surface, with shorter thinner hairs covering the basal three-fourths of the uropatagium (Fig. 2D).

COMPARISONS. $V$. brocki differs from $V$. nymphaea in being much smallerforearm, 32.4 compared with 36 to 38; skull (greatest length), 17.8 compared with 20.5 to 21.5 ; condylobasal length 15.5 compared with 17.9 to 20; zygomatic breadth 10.4 compared with 11.7 to 12.4 . The pelage on the dorsum is strongly tricoloured, with a dark base, light central region and dark tips compared with a quadracolour pattern of a paler dark basal band, a darker pale central band and the addition of light tips to the darker 

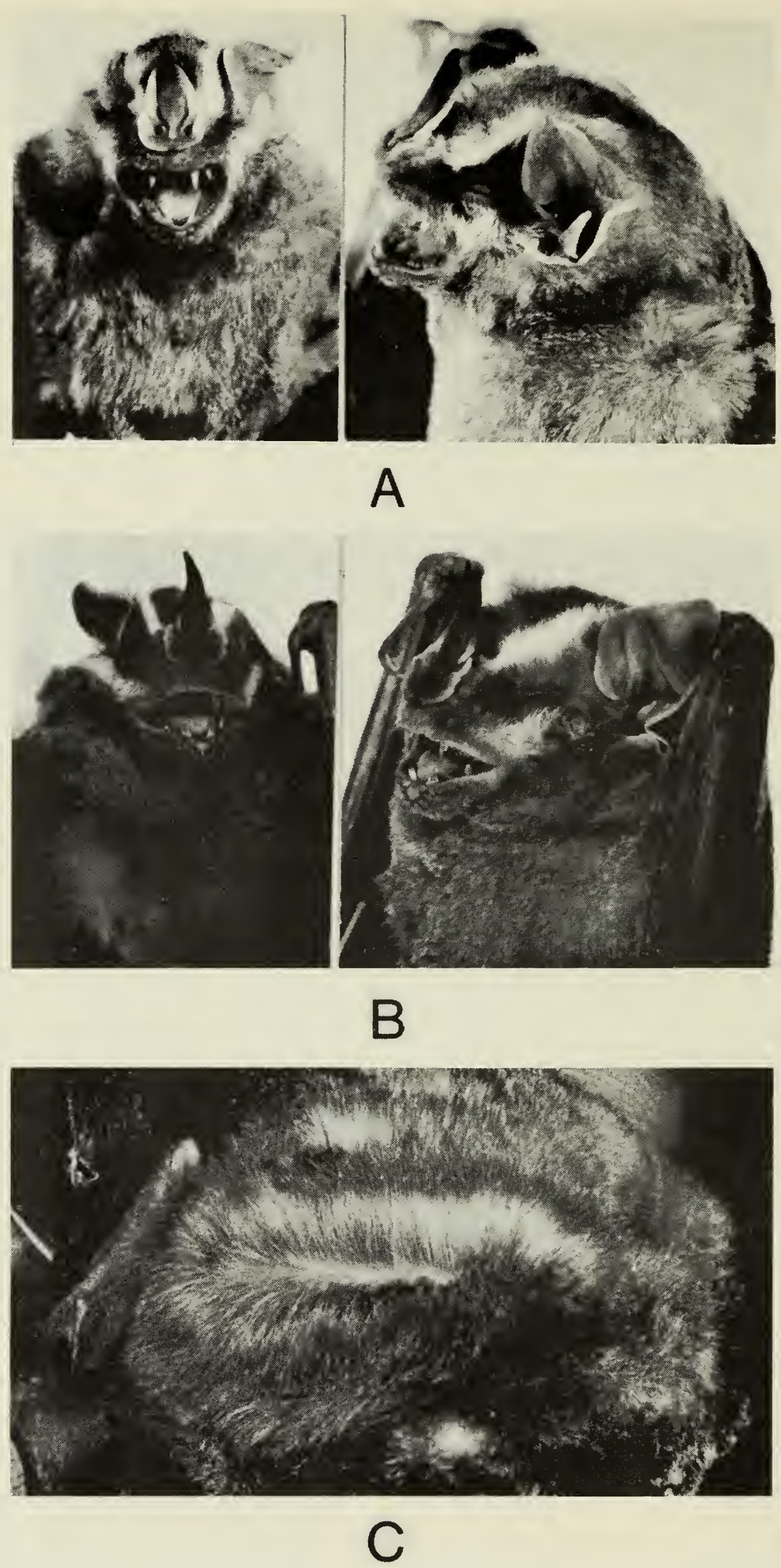

Fig. 2-a, Holotype of Vampyressa brocki (front and lateral view of head). $b$, V. bidens (R.O.M. 37297 ô from Guyana); $c$, dorsal pelage of $V$. brocki showing banding of hairs; 


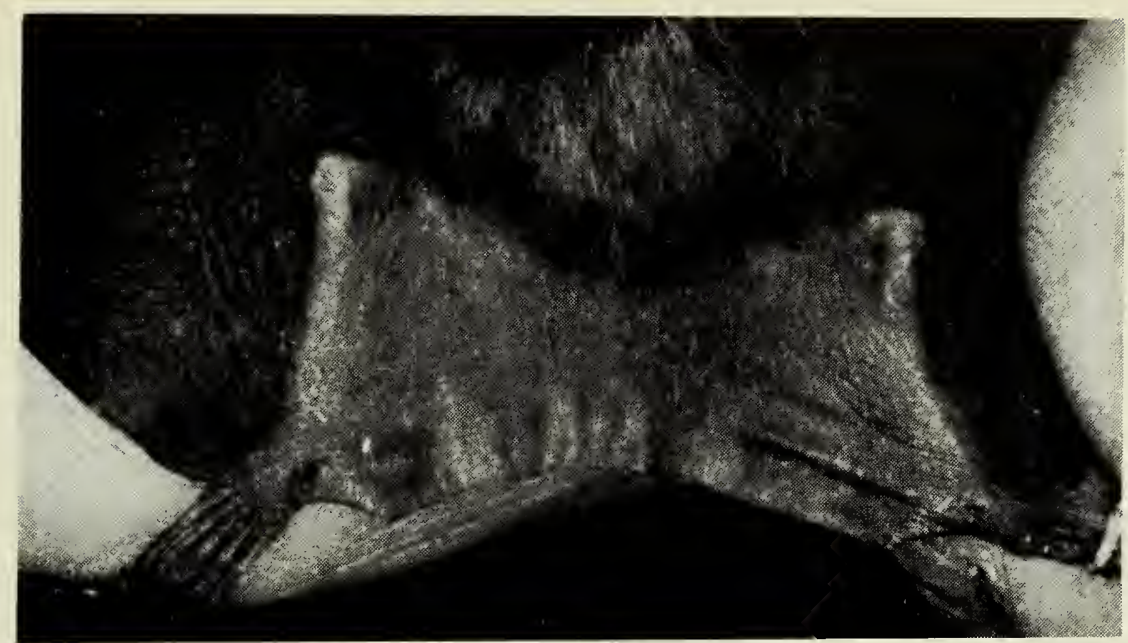

D

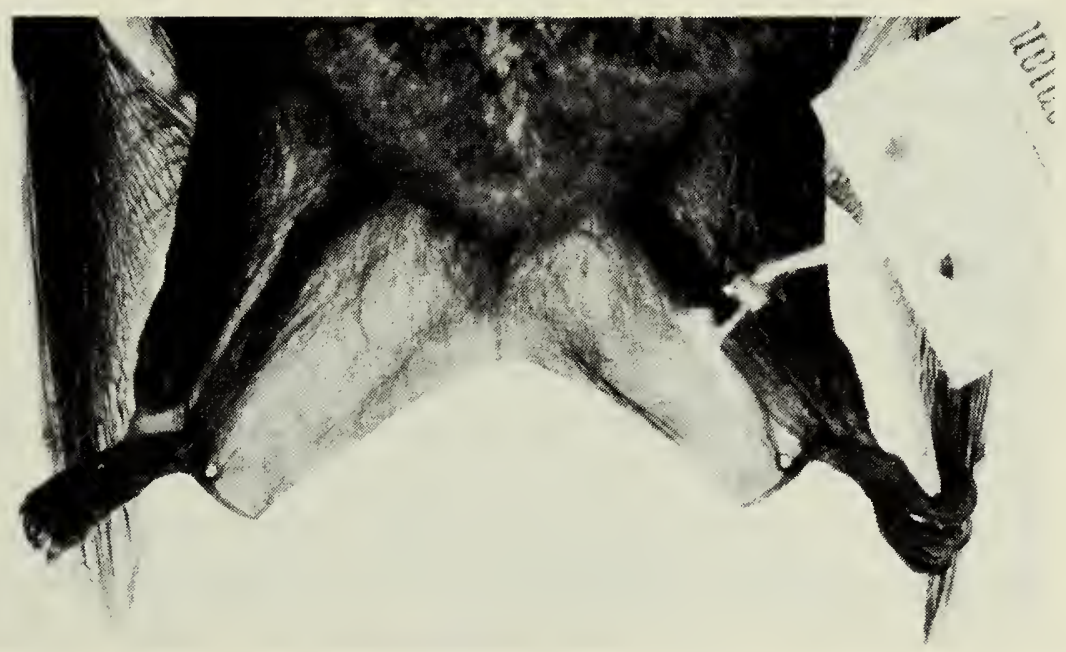

$E$

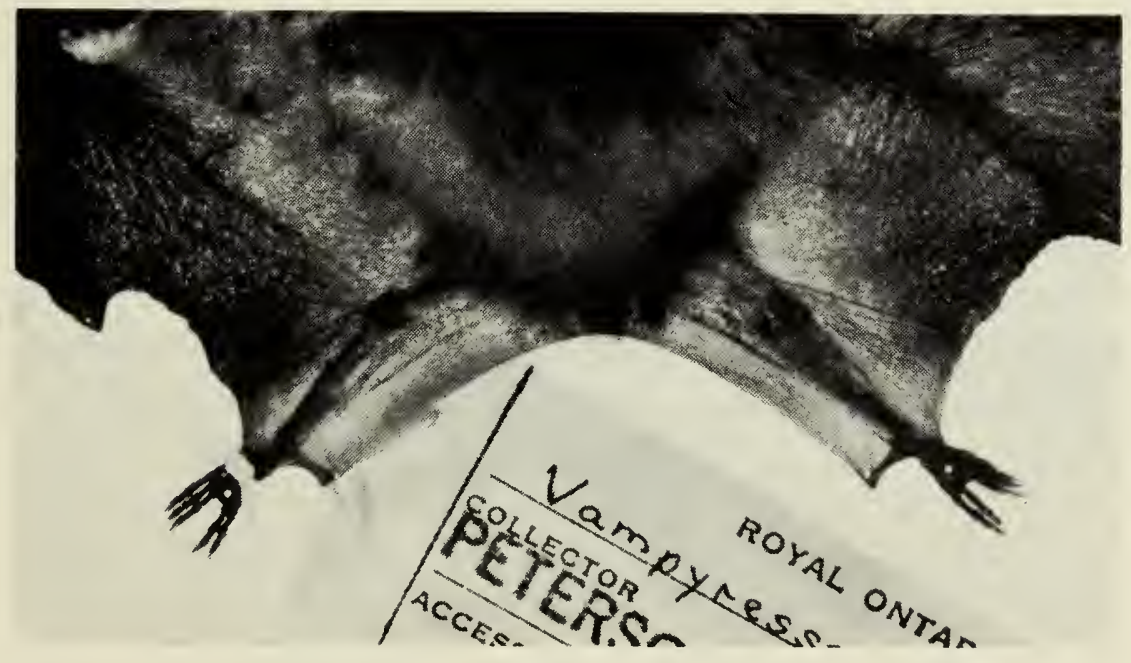

$F$

Fig. 2-d, interfemoral membrane of $V$. brocki holotype; e, same of $V$. nymphaea (U.S.N.M. 30403 \& from Canal Zone); $f$, same of $V$. pusilla thyone (R.O.M. 33614 o from British Honduras). 
terminal band (see Fig. 2C). The interfemoral membrane is apparently broader, less incised at the midline and slightly more hairy on the basal three-fourths of the upper surface (see Fig. 2D and E). The dorsai profile of the skull has a less abrupt angle between the rostrum and the frontal region, and the brain case is relatively shorter (see Fig. 5). The anterior nasal aperature is relatively wider and shorter, with a straighter posterior margin (viewed from above, see Fig. 4). The posterior margin of the palate has a distinct median projection compared with a more truncate margin, with a slight median projection in some specimens (this character may prove to vary when more examples of $V$. brocki are known). The upper incisors are relatively long and close together, with no indication of bilobation in the type, whereas in most specimens of $V$. nymphaea there is an indistinct bilobation, although some examples of the latter match the type closely. Additional specimens of $V$. brocki may show some bilobation similar to $V$. nymphaea. The anterior upper premolar is relatively smaller, being approximately 30 per cent narrower than the posterior one, as compared with only five to 15 per cent in $V$. nymphaea. The inner region (heel) of both $\mathrm{M}^{1}$ and $\mathrm{M}^{2}$ is relatively narrower in relation to the anterior-posterior length of the outer cusps, and $\mathrm{M}^{2}$ has a more distinct posterior angle between the heel and the outer cusps than in $V$. nymphaea.

Compared with $V$. pusilla thyone (including minuta and venilla), $V$. brocki is approximately the same size but darker in dorsal pelage, with a more contrasting tricoloured pattern and with an indistinct mid-dorsal stripe and strongly contrasting dark orbital, white supraorbital and suborbital stripes. The mid-rib of the lancet of the nose-leaf is more prominent. Pale coloration extends from the side of the basal plate of the nose-leaf onto the lateral flanges of the lancet and ends behind the spike (see Fig. $2 \mathrm{~A}$ ), whereas in $V . p$. thyone the light area is confined to the lateral edges of the basal plate.

The tragus differs in basic shape (see Fig. 3), although the extent of individual variation is unknown and thus may be of limited taxonomic significance. The ear likewise differs in some details, particularly in the conformation of the basal lobe. The interfemoral membrane is broader, with the central margin being approximately equal to the length of the tibia and virtually naked on the terminal quarter, whereas in $V$. pusilla it is much

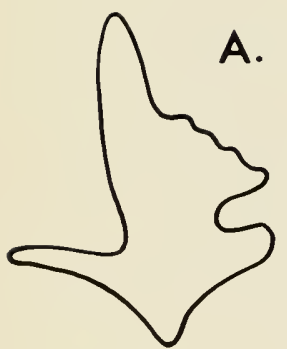

33614 ㅇ

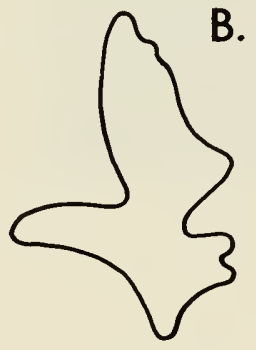

309888 \&

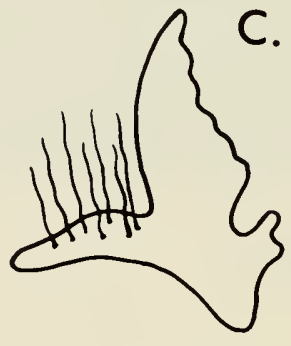

38515 우
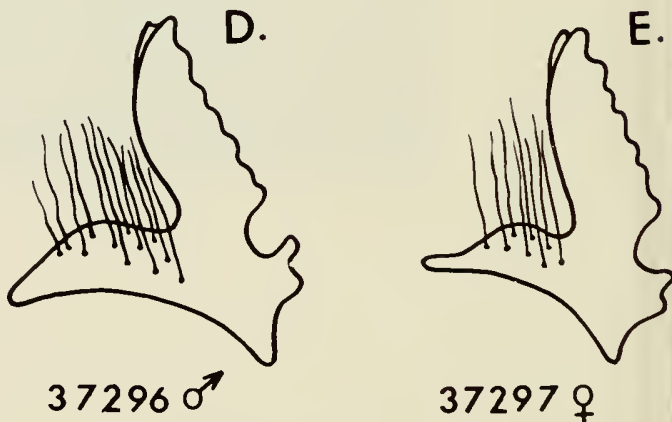

37297 \&

Fig. 3-Tragus variation in the genus Vampyressa; $a, V$. pusilla thyone (from dried skin); $b, V$. nymphaea (from dried skin); $c, V$. brocki (holotype); $d$, and $e, V$. bidens, male and female. 
narrower and near the length of the calcar, with the lateral area nearly naked but with a conspicuous fringe of hair in the centre (see Fig. 2D and F).

In the skull the shape of the anterior nasal aperature differs in basic outline when viewed either anteriorly or dorsally (see Fig. 4), with that of $V$. brocki appearing horizontally broad and vertically narrow to form a as in $V$. bidens, whereas in $V$. pusilla the sides slope to approach a $\checkmark$ shape, particularly in the older adults when viewed from the front. Young individuals tend to have a flattened base in the bottom of the $\checkmark$ (the type of $V$. venilla and A.M.N.H. No. 31501 from Venezuela). The posterior margin of the palate has a distinct median projection which is absent in $V$. pusilla.

In the type of $V$. brocki the inner upper incisors are in near contact with each other and are not bilobed, whereas most adult specimens of $V$. pusilla have a space between, and all known specimens are bilobate. The anterior upper premolar is in contact with the canine with a space between it and the posterior premolar, whereas in $V$. pusilla the anterior premolar is approximately equidistant between the canine and posterior premolar. The posterior upper premolar is more truncate posteriorly with its border parallel with $\mathrm{M}^{1}$, whereas in $V$. pusilla the inner lobe is more reduced, and there is only a slight contact, if any with $\mathbf{M}^{1}$. In $V$. brocki the inner lower incisors are slightly smaller than the outer, whereas in $V$. pusilla they are more nearly sub-equal or the reverse. In $V$. brocki the anterior lower premolar in lateral profile is lower and the anterior marginal profile provides a blade-like shape, whereas in $V$. pusilla it is higher and the straight anterior margin gives a spear-like profile (see Fig. 5). $M_{1}$ is similar in both species, but the conformation of $\mathbf{M}_{2}$ provides a fundamental difference with that of $V$. brocki, being longer and narrower with a shallow sculpturing between the lower anterior and posterior cusps, whereas in $V$. pusilla $\mathbf{M}_{2}$ is shorter and broader with deep sculpturing between the higher anterior and posterior cusps.

Compared with $V$. melissa (forearm, 37.5; skull, greatest length, 21.5; condylobasal length, 20), $V$. brocki is much smaller, has more distinct orbital strips, lacks $\mathbf{M}_{3}$ and differs in other cranial details.

Compared with $V$. natteri, $V$. brocki differs in most of the same characters as from $V$. pusilla, except that $V$. natteri is larger (forearm, 35; skull, greatest length, 20.1; condylobasal length, 18.3; vide Goodwin, $1963)$. For the status of $V$. natteri see below.

Vampyressa brocki has a striking resemblance to Vampyriscus bidens in most characteristics except for its two rather than one pair of lower incisors and two instead of three lower molars (see below).

\section{Systematic Review}

In reviewing the subfamily Stenoderminae, Miller (1907) elevated the subgenera of Vampyrops as defined by Thomas (1900) to the status of full genera, i.e., Vampyrops, Vampyrodes, Vampyriscus and Vampyressa. 


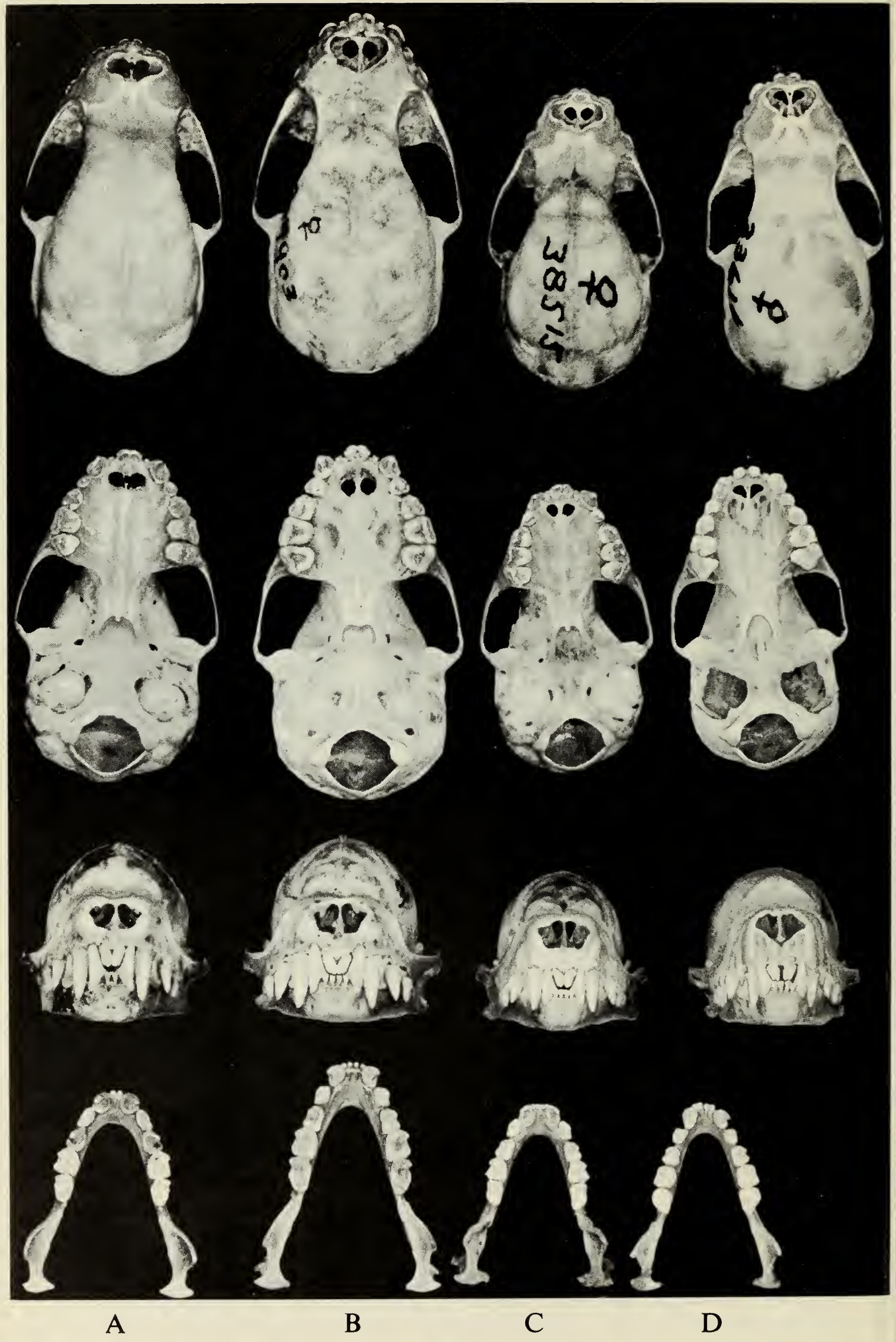

Fig. 4-Dorsal, ventral and anterior views of the skulls of four species of Vampyressa; $a, V$. bidens (R.O.M. 37297 \& except anterior view A.M.N.H. 67998 of); $b, V$. nymphaea (U.S.N.M. 34903 o) ; $c, V$. brocki (holotype); d, V. pusilla thyone (R.O.M. 33614 \&). 

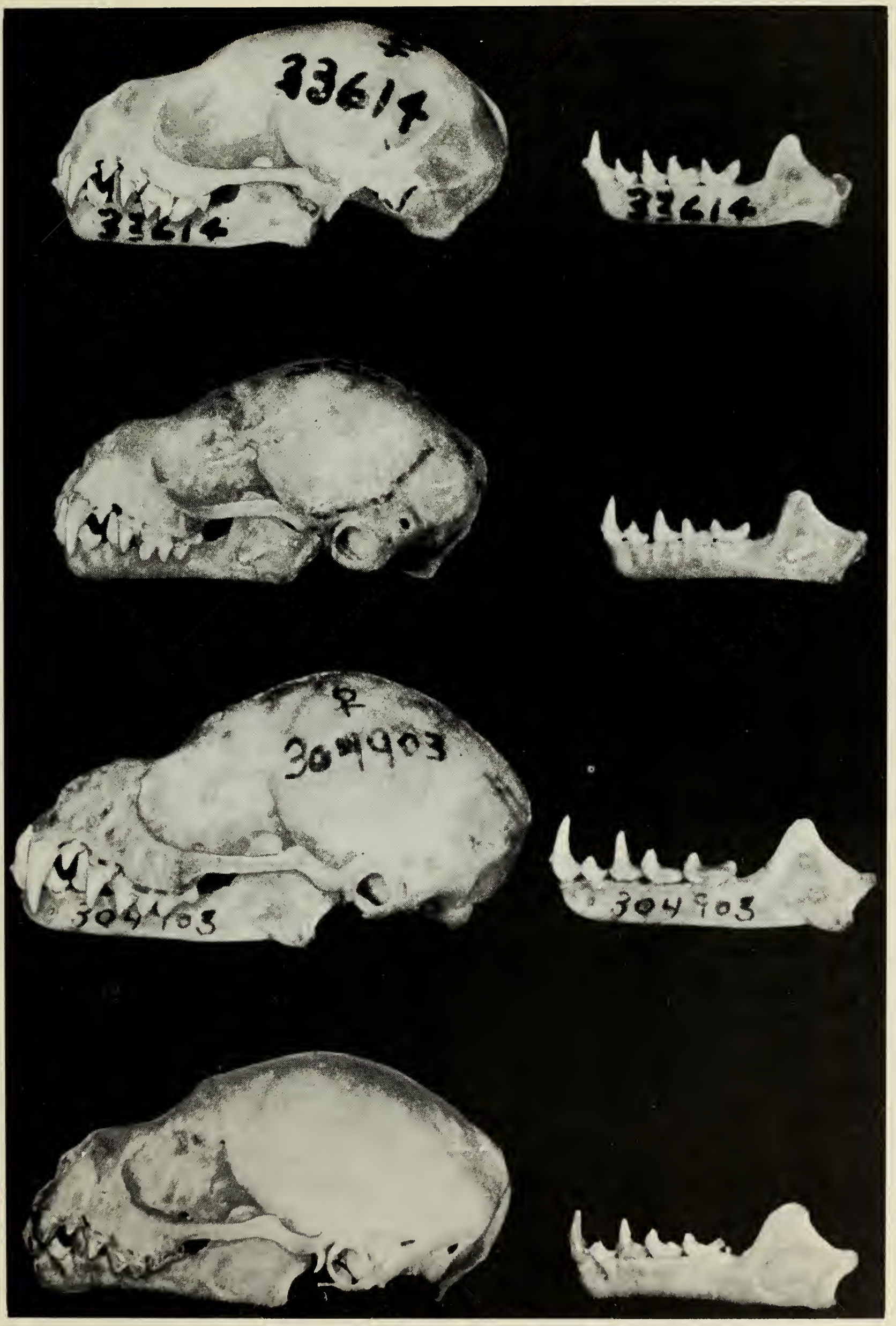

Fig. 5-Lateral views of four species of Vampyressa. Top to bottom: V. pusilla throne, V. brock, V. nymphaea and $V$. biden.

9 
The genus Vampyrops shares a dental formula of $\mathrm{I} \frac{2}{2}, \mathrm{C} \frac{1}{1}, \mathrm{P} \frac{2}{2}, \mathrm{M} \frac{3}{3}=32$ with a number of other genera, including Uroderma, Enchisthenes, Brachyphylla, Ardops and some species of Artibeus. Ardops is readily distinguished by the interpterygoid space extending forward as a deep palatal emargination. Miller (1907) showed that Brachyphylla shares with Vampyrops a first lower molar that has a distinct postero-internal cusp with the shape of the crown being very different from that of the last premolar, but the two differ in that Brachyphylla has the crowns of molars above and below heavily wrinkled; the second upper molars have a large protocone; and the upper canine has a large secondary cusp. Miller distinguished Uroderma, Artibeus and Enchisthenes primarily on the basis of the conformation of the upper incisors, with Uroderma further characterized by its greater relative length and depth of rostrum, and Enchisthenes by its low entire inner upper incisors in combination with well developed $\mathrm{M}^{3}$ and $\mathbf{M}_{3}$. Externally Uroderma and Vampyrops are similar, and the dentition of the lower jaws of these two genera differ only in minor detail ( $c f$. U. bilobatum and $V$. helleri). Since the shape (length and depth) of the rostrum is relative, and the relative shape and size of the upper incisors may be obscured by loss or wear, additional characters to distinguish these two genera are desirable. Uroderma retains a distinct hypocone on $\mathrm{M}^{1}$ and $\mathrm{M}^{2}$, not unlike that of Artibeus but not so extremely developed, whereas in Vampyrops there is no distinct hypocone, the posterior-internal portion of the crown (heel) sloping smoothly downward from the anterior-internal cusp (protocone). The third upper molar is more fully developed in Uroderma than Vampyrops.

The genus Vampyrops contains a number of species (see Sanborn, 1955) and apparently represents an evolutionary branch, more specialized than Uroderma, from which other superficially similar forms have evolved. The loss of the hypocone in the upper molars foreshadows further reduction in the molars as seen in Vampyressa and the more extreme reduction as seen in Ectophylla.

Vampyrodes was distinguished as a subgenus of Vampyrops by Thomas (1900) with Vampyrops caraccioli Thomas (1889) as the type species on the basis of a dentition of $\frac{2}{3}$ molars in combination with $\frac{2}{2}$ incisors, although he later described a bat, Vampyressa melissa (Thomas, 1926) with the same dental formula. The latter is not closely related to Vampyrodes, however, which appears to represent an independent line of evolution characterized by a well developed antero-internal cusp (protocone) and a weakly developed protoconule between the protocone and paracone on both $\mathrm{M}^{1}$ and $\mathrm{M}^{2}$; an intermediate cusp between the paraconid and protoconid as well as a distinct metaconid on $\mathrm{M}_{2}$ (see Fig. 6). The distinctive dental characteristics of Vampyrodes set it apart from the other forms originally aligned with Vampyrops, i.e. Vampyressa and Vampyriscus.

Vampyressa was originally based on Phyllostoma pusillum Wagner (Thomas, 1900), and its definition as a genus was also based solely on this species by Miller (1907). Later, when Thomas (1909) described Vampyressa nymphaea, he stated (p. 231) "This species is so different from $V$. pusilla in the shape of its teeth as to induce a doubt as to whether it is 
rightly referred to this genus." Thomas also described $V$. thyone (1909), $V$. venilla (1924) and $V$. melissa (1926). Miller (1912) described $V$. minuta, which was subsequently regarded as a synonym of $V$. thyone by Hershkowitz (1949), Goodwin (1963) and Handley (1966). The genus Vampyressa was reviewed by Goodwin (1963), who re-examined the type of $V$. pusilla (Wagner, 1843) and concluded that $V$. thyone Thomas (1909) and $V$. venilla Thomas (1924) should be arranged as races of $V$. pusilla. Goodwin described $V$. natteri on the basis of a single specimen of uncertain origin, date and collector but assumed to be from Ipanema, District of São Paulo, Brazil. The type of $V$. natteri appears fundamentally indistinguishable from the type of $V$. pusilla except for size and the degree of separation of the upper inner incisors. As indicated by Handley (1966), this latter character is subject to alteration with age. The type of $V$. natteri is clearly a fully adult specimen, and that of $V$. pusilla is quite obviously of a young individual. Since the two specimens represent the only individuals now known from the whole of southern Brazil, the evidence seems strongly conclusive that $V$. natteri is in fact only an adult of the same taxon as $V$. pusilla. The type of $V$. venilla shows close similarity in all basic characters with $V$. thyone and is here regarded as a synonym for it.

Vampyriscus bidens, originally described as Chiroderma bidens by Dobson (1878), has a dental formula of $\mathrm{I}_{\frac{1}{1}}, \mathrm{C}_{\frac{1}{1}}, \mathrm{P}_{\frac{2}{2}}, \mathrm{M}_{\frac{2}{3}}=28$. Thomas (1889) transferred the species to Vampyrops but later (1900) separated it as a subgenus of the latter under the name Vampyriscus based on its dental combination of incisors $\frac{2}{1}$ and molars $\frac{2}{3}$. Miller (1907) elevated the subgenus to generic rank but listed it erroneously as having only $\frac{2}{2}$ molars.

A comparison of Vampyressa brocki and V. nymphaea with Vampyriscus bidens reveals many striking similarities, particularly in the conformation of the post-canine teeth, and these two species are actually more similar to $V$. bidens than to $V$. pusilla and $V$. melissa. The only major difference observed is the loss of one pair of lower incisors and the retention of $\mathrm{M}_{3}$ in bidens (see Figs. 4, 5 and 6). In general the post-canine teeth of brocki, nymphaea, and bidens show an obvious derivation from the Vampyrops line, with bidens having evolved somewhat further with the loss of one pair of lower incisors. The similarity in the shape of the tragus and of the nose-leaf as well as the presence of a white dorsal stripe provide further evidence of a close affinity of bidens, brocki and nymphaea.

The molar teeth of $V$. pusilla and $V$. melissa have become more strongly modified from the Vampyrops line and appear to represent an independent line of evolution, perhaps diverging toward the direction of Ectophylla with its even greater reduction in molar size.

The basic similarities of melissa, pusilla, nymphaea, brocki and bidens suggest that they should be united within one genus, while their diversity suggests three different lines of evolution from a basic Vampyrops-like base, with nymphaea and brocki representing one line, bidens a second, and pusilla and melissa the third. Of the various alternatives available, the existing evidence suggests that the Genus Vampyressa should be retained to include the above, and that the three lines of evolution within it would 


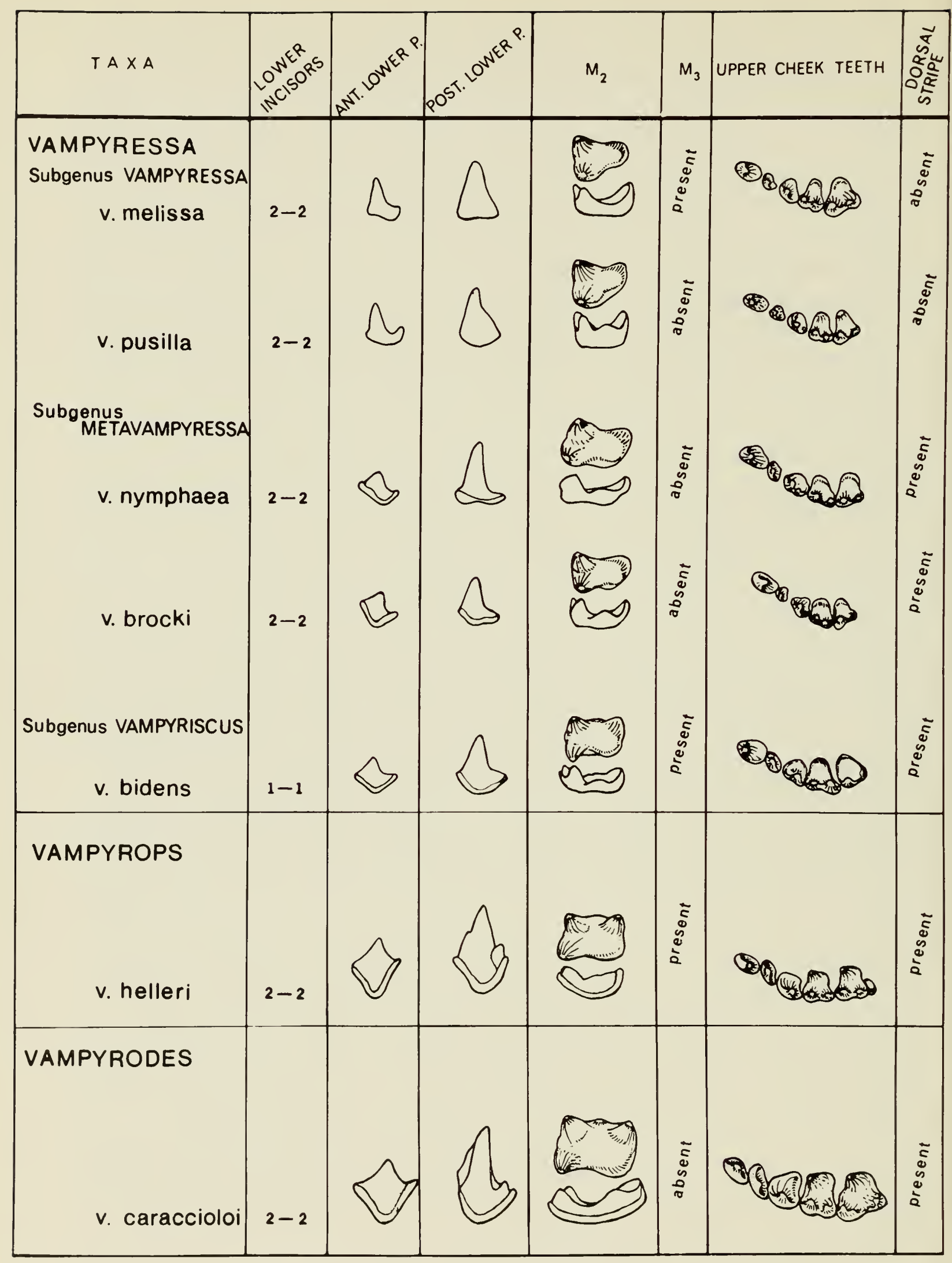

Fig. 6-Diagrammatic summary of major characters in the genus Vampyressa and related genera. 
best be expressed by designating them as subgenera. Vampyriscus is available for the subgenus represented by bidens as the type species. Vampyressa could again be used as a subgenus containing $V$. melissa and pusilla as the type species. It is necessary to create a third subgenus, which I propose to be known as

\section{Metavampyressa subgen. $\mathrm{n}$.}

with Vampyressa nymphaea as the type species and to include $V$. brocki.

An outline of this organization of the genus Vampyressa and its relation to Vampyrops and Vampyrodes is shown in Fig. 6.

The genus Vampyressa must therefore be redefined as follows: small to medium size Stenoderminae bats with Vampyrops-like upper dentition but with only two upper molars; with the inner cusp (on the heel) reduced in height on $\mathrm{M}^{1}$ and obsolete on $\mathrm{M}^{2}$; with two pair of upper incisors, the inner being relatively long and narrow, usually more than twice the height of the outer pair; with lower incisors, either one or two pair; with posterior lower premolars simple, with a single high cone-like cusp (compared with a blade-like structure with small anterior and posterior cusps in Vampyrops and a more complex tricuspidate condition in Vampyrodes) (see Fig. 6); and with either two or three lower molars.

\section{Key to Known Species and Subspecies of the Genus Vampyressa}

1. One pair of lower incisors

V. bidens

Two pair of lower incisors

2. $\mathrm{M}_{3}$ present V. melissa

$\mathrm{M}_{3}$ absent

3. $\mathrm{M}_{2}$ approximately as long as wide with high anterior and posterior cusps

$\mathrm{M}_{2}$ longer than wide with low anterior and posterior cusps

4. Forearm in full adults more than $34 \mathrm{~mm}$.

Forearm in full adults less than $34 \mathrm{~mm}$.

5. Forearm in full adults more than $34 \mathrm{~mm}$., greatest length of skull more than $20 \mathrm{~mm}$.

V. pusilla pusilla

V. pusilla thyone

Forearm in full adults less than $34 \mathrm{~mm}$, greatest length of skull less than $20 \mathrm{~mm}$.

V. nymphaea V. brocki

\section{Genus Vampyressa (Thomas)}

The following abbreviations are used: A.M.N.H.-American Museum of Natural History; B.M.-British Museum (Natural History) ; I.R.S.N.B.Institut Royal des Sciences Naturelles de Belgique; R.O.M.-Royal Ontario Museum; U.S.N.M.-United States National Museum.

Vampyressa (Vampyressa) pusilla pusilla (Wagner)

Phyllostoma pusillum Wagner, 1843, Abhandl, Münch. Akad. Wiss. Vol. 5, p. 173.

Chiroderma pusillum, Peters, 1866. M-Ber. Preuss. Akad. Wiss., p. 395. 
Stenoderma (Chiroderma) pusillum, Pelzeln, 1883. Brasilische Saligethiere, p. 34.

Vampyrops pusillus, Thomas, 1889. Ann. Mag. Nat. Hist., Ser. 6, Vol. 4, p. 170.

Vampyrops (Vampyressa) pusillus, Thomas, 1900. Ann. Mag. Nat. Hist., Ser. 7, Vol. 5, p. 270.

Vampyressa pusilla, Miller, 1907. Bull. U. S. Natl. Mus., Vol. 57, p. 156.

Vampyressa pusilla pusilla, Goodwin, 1963.

Vampyressa natteri Goodwin, 1963.

TYPE LOCALITY: Sapitiba, Rio de Janeiro, Brazil.

RANGE: Southeastern Brazil (Goodwin, 1963).

SPECIMENS EXAMINED: None (vide Goodwin, 1963).

Vampyressa (Vampyressa) pusilla thyone (Thomas)

Vampyressa thyone Thomas, 1909. Ann. Mag. Nat. Hist., Ser. 8, Vol. 4, p. 231.

Vampyressa minuta Miller, 1912. Proc. U. S. Natl. Mus., Vol. 42, p. 25. Vampyressa venilla Thomas, 1924. Ann. Mag. Nat. Hist., Ser. 9, Vol. 13, p. 533.

Vampyressa thyone, Hershkovitz, 1949. Proc. U. S. Natl. Mus., Vol. 99, p. 443.

Vampyressa pusilla thyone, Goodwin, 1963. Am. Mus. Novit., No. 2125, p. 12.

Vampyressa pusilla, Handley, 1966. Ectoparasites of Panama, Field Mus. Nat. Hist., p. 767.

TYPe Locality: Chimbo, near Guyaquil, Bolívar Prov., western Ecuador. RANGE: Northwestern South America from southeastern Peru north to northern Colombia and Las Quignas, Venezuela (Goodwin, 1963), Central America from Panama (Handley, 1966), Costa Rica (Goodwin, 1963), Nicaragua (Starrett and de la Torre, 1964), Chiapas, Mexico (Davis, Carter and Pine, 1964), and British Honduras (Peterson, 1965).

SPECIMENS EXAMINED: British Honduras-R.O.M., Rockstone Pond, 33614 9. Costa Rica-A.M.N.H., Cañas Gordas, 141996 o and 141997 o . Colombia-A.M.N.H., Macarena Mts., 142152 o . Ecuador -A.M.N.H., Boca Curaray, 71675 ô, 71680 ô ; San José, 67991 q,

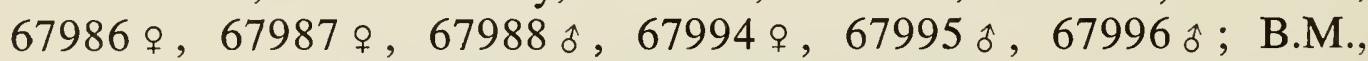
Chimba, 97.11.7.77 ô, 97.11.7.78 o . Ecuador/Peru-I.R.S.N.B., Rio Pastaza 7/11698 o . Peru-A.M.N.H., Río Suno 67991 ò ; B.M., San Lorenzo, 24.3.173 \& (type of $V$. venilla Thomas)

Vampyressa (Vampyressa) melissa Thomas

Vampyressa melissa Thomas, 1926. Ann. Mag. Nat. Hist., Ser. 9, Vol. 18, p. 157.

Type locality: Puca Tambo, Peru.

RANGE: Known only from the type locality.

SPECIMENS EXAMINED: None (vide Goodwin, 1963). 
Vampyressa (Metavampyressa) nymphaea Thomas

Vampyressa nymphaea Thomas, 1909. Ann. Mag. Nat. Hist., Ser. 8, Vol. 4, p. 230.

TYPE LOCALITY: Novita, Río San Juan, Chocó, Colombia.

RANGE: Western Colombia and north to the Canal Zone, Panama (Goodwin, 1963; Handley, 1966).

SPECIMENS EXAMINED: Panama-U.S.N.M., Barro Colorado Is., Canal Zone, 304903 \% ; Tacarcuna Village, Darién, 309888 \% ; Río Seteganti, Darién, 318130 ô ; Cerro Azul, Panama, 323439 ô.

Vampyressa (Metavampyressa) brocki, spec. nov.

TYPE LOCALITY: Kuitaro River, 40 mi. E. of Dadanawa, Rupununi Dist.,

Guyana.

RANGE: Known only for type locality.

SPECIMENS EXAMINED: Guyana-R.O.M., 38515 o (the type).

Vampyressa (Vampyriscus) bidens (Dobson)

Chiroderma bidens Dobson, 1878. Cat. Chiroptera Brit. Mus., p. 535. Vampyrops bidens, Thomas, 1889. Ann. Mag. Nat. Hist., Ser. 6, Vol. 4, p. 170.

Vampyrops (Vampyriscus) bidens, Thomas, 1900. Ann. Mag. Nat. Hist., Ser. 7, Vol. 5, p. 270.

Vampyriscus bidens, Miller, 1907. Bull. Am. Mus. Nat. Hist., Vol. 57, p. 157.

TYPE LOCALITY: Río Huallaga, Peru.

RANGE: Ecuador and Perú (Sanborn, 1936), Western Brazil (Vieira, 1942;

Cabrera, 1957) to Guyana (Hill, 1964).

SPECIMENS EXAMINED: Ecuador-A.M.N.H., San José, 67997 î, 67998 ô ;

Boca Cururay, 71656 o . Peru-A.M.N.H., Mazan R., 98780 ô ; Urubamba, Boca R., 76090 \% ; Luisiana, Apurimac R., Cuaco, 208072 q. B.M., Tuscamo, Masisea, Río Ucayali, 24.3.1.66 ô. Guyana-R.O.M., Rupununi Dist., Kuitaro R., Curary Wau, E. of Shea, 37296 ô, 37297 o ; Bonowau, near Shea, 44420 ô .

\section{OTHER SPECIMENS EXAMINED}

Vampyrops helleri: Guyana-R.O.M., Rupununi Dist., Nappi Creek, Kanuku Mts., 25 mi. E. Letham, 31749 o ; Kuitaro R., Sheebee Wau, 35932 of ; Maruranowa, near Dadanawa, 37948 o ; Kanashen (WaiWai Village), upper Essequibo R., 36042 \& ; Peru-B.M., Río Marañón, San Lorenzo, 24.3.1.57 \& ; Colombia--R.O.M., Mocoa, Putumayo, 34572 수 , 40359 우

Vampyrops lineatus: Brazil-B.M., Ceará, 11.4.25.5 ô ; Rio Doce, Espiritu Santo, 23.12.12.9 o (type of V. L. sacrillus, Thomas). ParaguayParis Museum, 194 (type).

Vampyrops dorsalis: Venezuela-B.M., Galipare, Cerro del Avilo near Caracas, 14.7.27.1 of (type of $V$.oratus, Thomas).

Vampyrops recifinus: Brazil-B.M., Pernambuco, 81.2.16.4 ô (type). 
Vampyrops vittatus: Venezuela-B.M., San Esteban, 11.5.25.115 $\delta$. Ecuador/Peru-I.R.S.N.B., Río Pastaza, 42/11698 o .

Vampyrodes caraccioli caraccioli: Trinidad-R.O.M., 88.6.1.1 $\hat{\text { o . }}$.

Vampyrodes caraccioli major: Peru-B.M., Río Marañón, San Lorenzo, 24.3.1.62 $\%$;24.3.1.63 + (type of $V$. ornatus, Thomas).

\section{Acknowledgments}

This study, arising out of our bat research program, has had the financial support of the National Research Council of Canada, the Canadian National Sportsmen's Show (through the office of its chairman, Mr. Frank H. Kortright), and the Royal Ontario Museum, University of Toronto. Mr. Stanley Brock of Dadanawa, Guyana, has contributed invaluable material and data and deserves special thanks. Mr. John Edward Hill kindly arranged for additional photographs of the type of Vampyressa venilla Thomas and greatly facilitated my studies during my visits to the British Museum (Natural History). Dr. Charles O. Handley, Jr., provided the loan of comparative material of Vampyressa nymphaea Thomas from the United States National Museum. Drs. Richard Van Gelder and Karl Koopman extended much assistance and co-operation in my studies carried out in the Department of Mammalogy of the American Museum of Natural History. A collection of New World bats of the Institut Royal des Sciences Naturelles de Belgique submitted to the author for identification by Dr. Xavier Misonne provided valuable comparative material. I wish to acknowledge the valued assistance of many staff members of the Royal Ontario Museum, especially to Mr. James Borack, Mrs. Diana Young, Miss Eleanor Feely, Mrs. Sophia Poray, Mr. T. M. Shortt, Mr. Paul Geraghty and Mr. Leighton Warren. Dr. J. R. Tamsitt provided much council as well as editorial and other assistance.

\section{Literature Cited}

CABRERA, A.

1958 Catálogo de los mamíferos de América del Sur. Rev. Mus. Argent. Cienc. Nat., Buenos Aires, Tomo 4, No. 1, pp. 1-307.

DAVIS, WILLIAM B., DILFORD C. CARTER, and RONALD H. PINE

1964 Noteworthy records of Mexican and Central American bats. Jour. Mamm., Vol. 45, No. 3, pp. 375-387.

DOBSON, GEORGE E.

1878 Catalogue of the Chiroptera in the collection of the British Museum. London. pp. 1-567.

GOODWIN, GEORGE G.

1963 American bats of the genus Vampyressa with the description of a new species. Am. Mus. Novitates, No. 2125, pp. 1-24.

HANDLEY, CHARLES O., JR.

1966 Checklist of the mammals of Panama in Ectoparasites of Panama. Field Mus. Nat. Hist., (861 pp.), pp. 753-795. 
HERSHKOVITZ, PHILIP

1949 Mammals of northern Colombia, Preliminary Report No. 5: Bats (Chiroptera). Proc. U.S. Natl. Mus., Vol. 99, No. 3246, pp. 429454.

HILL, J. E.

1964 Notes on bats from British Guiana with the description of a new genus and species of Phyllostomidae. Mammalia, Tome 28, No. 4, pp. 533-572.

MILLER, GERRIT S., JR.

1907 The families and genera of bats. Bull. U. S. Natl. Mus., Vol. 57, pp. 1-282.

1912 A small collection of bats from Panama. Proc. U. S. Natl. Mus., Vol. 42, pp. 21-25.

PETERSON, R. L.

1965 The genus Vampyressa recorded from British Honduras. Jour. Mamm., Vol. 46, No. 4, p. 676.

SANBORN, COLLIN C.

1936 Records and measurements of Neotropical bats. Zool. Ser. Field Mus. Nat. Hist., Vol. 20, No. 13, pp. 93-106.

1955 Remarks on the bats of the genus Vampyrops. Fieldiana: Zool., Vol. 37, pp. 403-413.

STARRETT, ANDREW, and LUIS DE LA TORRE

1964 Notes on a collection of bats from Central America, with the third record for Cyttarops alecto Thomas. Zoologica, Vol. 49, pp. 53-63.

THOMAS, OLDFIELD

1889 Description of a new Stenodermatous bat from Trinidad. Ann. Mag. Nat. Hist., Vol. 4, Ser. 6, pp. 167-170.

1900 Descriptions of new Neotropical mammals. Ann. Mag. Nat. Hist., Vol. 5, Ser. 7, pp. 269-274.

1909 Notes on some South American mammals with descriptions of new species. Ann. Mag. Nat. Hist., Vol. 4, Ser. 8, pp. 230-242.

1924 On a collection of mammals made by Mr. Latham Rutter in the Peruvian Amazons. Ann. Mag. Nat. Hist., Vol. 13, Ser. 9, pp. 530538.

1926 The Godman-Thomas expedition to Peru. III-On mammals collected by Mr. R. W. Hendee in the Chachapoyas region of north Peru. Ann. Mag. Nat. Hist., Vol. 18, Ser. 9, pp. 156-167.

VIEIRA, CARLOS O. DA CUNHA

1942 Ensaio Monográfico sobre os Quirópteros do Brasil. Arquivos de Zoologia do Estado de São Paulo, Vol. 3, Art. 8, pp. 219-471. 



(2) 112 


\section{LIBRARY}

ROYAL ONTARIO MUSEUM 

